\title{
PROBLEMS OF VERIFYING THE AUTHENTICITY OF ASYLUM SEEKERS' DOCUMENTS AND IMPROVING THE IDENTIFICATION OF THESE PERSONS
}

\author{
Inna Šnipa1, Iluta Arbidāne ${ }^{2}$,Jel̦ena Volkova ${ }^{3}$ \\ ${ }^{1}$ Senior Inspector of the State Border Guard Examination Service, State Border Guard, \\ e-mail: Inna.Snipa@rs.gov.lv, Rēzekne, Latvia \\ ${ }^{2}$ Dr.oec, Professor, Rezekne Academy of Technologies, e-mail: Iluta.Arbidane@rta.lv, \\ Rēzekne, Latvia \\ ${ }^{3}$ Mg.oec., Lecturer, Rezekne Academy of Technologies, e-mail: \\ Jelena.Volkova@rta.lv, Rēzekne, Latvia
}

\begin{abstract}
The Republic of Latvia must be ready to implement the asylum procedure quickly and efficiently, improving the identification process, as the influx of asylum seekers into the EU may recur. The aim of the research is to study the asylum seekers identification procedure, the factors affecting it, and the possibilities for improving this procedure, to determine nature of the authentication process of documents presented by asylum seekers, to identify authentication problems and to find possible solutions. As a result of the research, the authors have evaluated the process of asylum seekers identification and developed proposals for its improvement, described the factors affecting the authentication of asylum seekers' documents and evaluated the possibilities to exclude these factors. The method of scientific induction, graphical method, document analysis, monographic or descriptive method are used in the research.
\end{abstract}

Keywords: asylum seeker, document authentication, identification of persons.

\section{Introduction}

The procedure for identification of asylum seekers is one of the most important steps in the asylum process, while the purpose of checking the authenticity of asylum seekers' documents is to use the results of technical examinations of the documents in the asylum process. During the verification of the authenticity of documents, the officials of the State Border Guard use the informative resources of specimen documents - the information systems for detection of false documents that are available throughout Europe. The use of the information systems speeds up the document verification process in cases of suspicion.

One of the duties of an asylum seeker in the Republic of Latvia is to cooperate with the State Border Guard so that it can take his/her fingerprints, photograph him/her and identify him/her. The identification of an asylum seeker and the verification of the authenticity of documents are performed directly by the officials of the State Border Guard, therefore it is necessary to improve these processes. The authenticity of asylum seekers' documents is checked or examined by the officials of the State Border Guard Examination Service. The Latvian legislation governing the area of 
migration does not provide a definition of identity for a third-country national and does not describe the process of verifying a person's identity, however, the identification process continues until unambiguously clear information about a person's identity is obtained.

The identification of an asylum seeker involves various stages: verification of fingerprints in the European Automated Fingerprint Identification System (Eurodac), verification of the authenticity of documents, appointment of various examinations, as well as other checks. Since 2016, a reform of the Eurodac Regulation has been proposed to improve and strengthen the European Union's information system with fingerprints of asylum seekers. At present, the Eurodac system has been introduced and is successfully operating in Latvia, including many functions that have not yet been implemented in other EU member states.

To determine the authenticity of documents, the officials of the State Border Guard use the specimens of documents uploaded in the document specimen information systems and their descriptions. The use of the information systems speeds up the document verification process, nevertheless the low quality of documents issued by the third countries presented by asylum seekers, the lack of specimens and errors made by the issuing authorities make it difficult to establish the authenticity of a document.

The aim of the research is to study the concept of asylum seekers, the identification procedure, the factors affecting it and the improvement of this procedure, to analyse the nature of authenticity of documents presented by asylum seekers, to identify the problems of authentication and to find possible solutions. In order to achieve the aim of the research, the authors have set the following research tasks: 1) to study the asylum seeker identification procedure, 2) to analyse the factors affecting the asylum seeker identification procedure, 3) to make proposals to improve efficiency and quality of the identification process, 4) to study authenticity examination process of the documents presented by asylum seekers, 5) to develop proposals for the improvement of the efficiency and quality of the document authentication process.

Hypothesis: Identification of asylum seekers and authentication of documents is an important procedure in the asylum process.

Research methods: scientific induction method, graphical method, document analysis, monographic or descriptive method.

A positive identification result will prevent threats to public order and security not only in the particular Member State but also throughout the European Union. 


\section{Research results and discussion}

The European Commission has always moved towards a common European asylum system in order to move towards an effective, fair and humane asylum policy. A more efficient and coherent asylum system had required a single and harmonized set of rules at the European Union level. Therefore, in 2016, the Commission proposed the establishment of common procedures for granting international protection status, common standards on the protection, rights and reception conditions of beneficiaries of international protection.

According to Frans Timmerman, First Vice-President of the European Commission: "The European Union needs an asylum system that is both effective and protective, based on common rules, the principles of solidarity and a fair division of responsibilities. Those who really need international protection will receive it quickly, but those who are not entitled to protection in the EU will be returned immediately."

These changes have established a common asylum procedure and ensured that asylum seekers are treated equally and appropriately, regardless the Member State where they lodge their application for asylum. At the same time, asylum seekers have clear responsibilities and tasks to prevent the secondary movement and abuse of the asylum procedure.

In Latvia, the common conditions of the European asylum system are fulfilled by directly implementing the EU instructions (Adijāne, 2019). In order to ensure compliance of the legislation of the Republic of Latvia with the requirements of the European Union, the new Asylum Law entered into force in 2016, which also introduced the requirements of the European Union in the field of asylum.

In the period from 2016 to 2018, 921 application from asylum seekers were received in the Republic of Latvia; most often the asylum was requested by Syrian and Russian nationals - according the statistics, these were 289 and 87 cases, respectively.

Table 1. Number of asylum seekers and status obtained in 2016 -2018

(created by the authors, based on Statistics of the State Border Guard)

\begin{tabular}{|c|c|c|c|}
\hline & $\mathbf{2 0 1 6}$ & $\mathbf{2 0 1 7}$ & $\mathbf{2 0 1 8}$ \\
\hline Asylum seeker & 350 & 395 & 176 \\
\hline Refugee status & 47 & 39 & 23 \\
\hline Alternative status & 107 & 259 & 24 \\
\hline
\end{tabular}

Analysis of the statistical data in the European Union countries shows that 2,488,135 applications were received from asylum seekers from 2016 to 2018; most often the asylum was requested by Syrian nationals - in 303,980 cases. 
Latvian legislation governing the field of migration does not provide a definition of identity for a third-country nationals. Latvian legislation does not describe the process of verifying a person's identity, for example, when a third-country national applies for a visa or residence permit in connection with employment, studies or family reunification.

The officials of the State border guard face various challenges in determining the identity of the third-country nationals. When accepting an asylum seeker's application, the state border guard officials may face the following problems: the asylum seeker presents false identity documents (may be partially forged or completely counterfeit); the asylum seeker presents documents belonging to another person; the asylum seeker does not have documents; the asylum seeker lies about himself and hides his identity; the asylum seeker does not want to cooperate with the State Border Guard officials; the asylum seeker hides his country of origin; the asylum seeker refuses to perform an examination (e.g. age examination); the asylum seeker refuses to provide fingerprints; the asylum seeker pretends to be mentally ill. Sometimes asylum seekers enter Latvia without documents, because persons, who have been intimidated while fleeing persecution in their own country, save their lives and often cannot bring documents, so they enter another country without them.

One of the main problems caused by asylum seekers themselves is the change of identity. The asylum seeker provides information about himself/ herself, name, date of birth, country of origin, etc., but after a while provides completely different information. These steps may be repeated several times. According the statistics, asylum seekers lodge applications for a variety of reasons. However, some of them do not need the state protection and receiving a refugee status or alternative status in the Republic of Latvia, and Latvia is used only as a transit country to move to other European Union countries.

As our lives become more computerized, the security systems are becoming increasingly important. The rapid development of biometric technology is making information more vulnerable to misuse. Due to the growing importance of technology and the need for protection and access restrictions, reliable identification and authentication of individuals is required (Yuhanim Hani Yahaya, 2019). Biometric identification is the comparison of a reference sample with all biometric data samples in the biometric data processing system in order to determine its matching with one of the biometric data samples in the biometric data processing system and, if a match is found, to establish the identity of the owner of the reference sample. Biometric technologies are based on personal biometric data, which is compared with the data of a specific person (Biometric Data Processing System Law). 
The Eurodac system is one of the key elements of the common asylum policy. Eurodac, or the European Automated Fingerprint Comparison System, is a tool for quick obtaining information on an asylum seeker detained internally or at the border in order to find out whether or not he or she has lodged for and received asylum in another European Union Member State, and if the Requirements of the Dublin Regulation are applicable to him/her. The Eurodac system makes it possible to significantly reduce the time normally required for the European Union countries to process asylum applications, thus helping those who really need asylum to receive a faster response to their asylum application and to identify effectively those who, possibly, wishes to take advantage of the European Union's asylum procedures for selfish purposes. At present, the Eurodac system is implemented in Latvia and is operating successfully, including many functions that have not yet been implemented in other European Union member states.

Of all the fingerprints uploaded into the Eurodac system in the European Union, 551,253 were those of asylum seekers being checked. Comparing 2017 and 2018, it can be concluded that the total number of fingerprints uploaded decreased by $15 \%$ in 2018. Comparing the total number of fingerprints of asylum seekers uploaded, it had also decreased by $13 \%$.

The following definition of an genuinne document can be found in Latvian legislation: it is a document identifying a person or certifying rights issued by an authorized institution, a visa, a stamp or seal imprint. In order to prove or exclude the authenticity of a document, a technical examination of the document may be assigned, where the expert gives his/her opinion. The expert opinion, as one of the means of proof, is playing an increasingly important role in criminal, civil and administrative proceedings.

The expert's opinion must be objective and scientifically substantiated in order to prevent persons from crossing the state border illegally by using false or impostor documents, to facilitate the identification of persons during immigration control and asylum proceedings, and to provide evidence in relevant procedural steps. One of the case-law scientists, Daniel C. Murrie, believes that "the objectivity of forensic experts is affected by a number of factors, one of them is responsibility and risk, which may endanger the forensic expert".

In the period from 2017 to 2019, the total number of asylum seekers' documents submitted for examination was 97. The lowest number of documents submitted for examination was 17 documents in 2017, then it increased to 39 documents in 2018, and reached the highest number -41 document in 2019. It should be noted that the highest compliance of documents with the specimens - namely, the number of recognition of the 
authenticity of documents was in 2019 , which was probably influenced by the proper updating of information in the document information systems and timely introduction of new specimens.
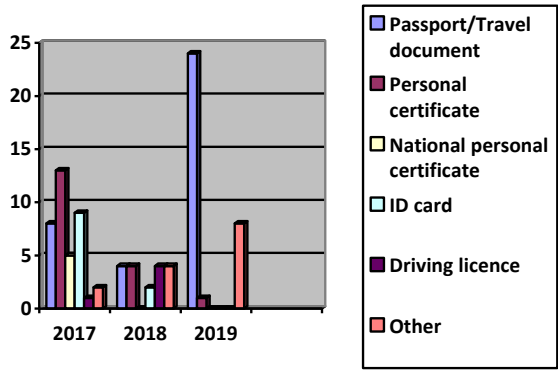

Figure 1. Asylum seekers' documents submitted for examination in $2017-2019$

(created by the authors, based on Statistics of the State Border Guard Examination Service)

It can be concluded that passports (37\%) are most often submitted documents among all the asylum seekers' documents.

Currently, a large number of document images (passports, personal ID cards, driving licenses, vehicle registration certificates, residence permits, etc.) have been uploaded into various systems with or without document descriptions. There are appropriate descriptions of images that relate to the specified document verification criteria, such as size, shape, security features (e.g. watermarks, UV light response, print quality, photo protection, etc.).

Within the framework of the research, a summary of information included in the information systems was created. The created table can be used by the officials in their work when searching for a specimen of the required document. The use of this table will help to reduce the time of the examination procedure as well as the waiting time for the person being examined.

Table 2. Information included in the information systems

(created by the authors)

\begin{tabular}{|c|c|c|c|c|c|c|c|c|c|c|}
\hline & 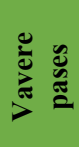 & $\frac{a}{a ̆}$ & $\frac{8}{8}$ & 音 & 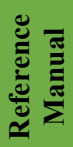 & $\begin{array}{l}n \\
\frac{0}{2}\end{array}$ & 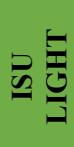 & 点 & $\begin{array}{l}\mathscr{2} \\
\varrho\end{array}$ & $\frac{\varangle}{z}$ \\
\hline $\begin{array}{l}\text { Travel } \\
\text { documents }\end{array}$ & $\mathrm{X}$ & $X$ & $X$ & $\mathrm{X}$ & $\mathrm{X}$ & $\mathrm{X}$ & $X$ & $X$ & $X$ & $X$ \\
\hline $\begin{array}{l}\text { Residence } \\
\text { permits }\end{array}$ & $\mathrm{X}$ & $X$ & $\mathrm{X}$ & $X$ & $\mathrm{X}$ & $X$ & $\mathrm{X}$ & $X$ & $X$ & $\mathrm{X}$ \\
\hline
\end{tabular}




\begin{tabular}{|c|c|c|c|c|c|c|c|c|c|c|}
\hline ID cards & $\mathrm{X}$ & $\mathrm{X}$ & $\mathrm{X}$ & $\mathrm{X}$ & $\mathrm{X}$ & $\mathrm{X}$ & $\mathrm{X}$ & $\mathrm{X}$ & $\mathrm{X}$ & $\mathrm{X}$ \\
\hline $\begin{array}{l}\text { Visa } \\
\text { specimens }\end{array}$ & $\mathrm{X}$ & $\mathrm{X}$ & $\mathrm{X}$ & $X$ & $\mathrm{X}$ & $\mathrm{X}$ & $\mathrm{X}$ & $\mathrm{X}$ & $\mathrm{X}$ & $\mathrm{X}$ \\
\hline $\begin{array}{l}\text { Civil status } \\
\text { documents }\end{array}$ & $\mathrm{X}$ & $\mathrm{X}$ & $X$ & $\mathrm{X}$ & $\mathrm{X}$ & - & - & - & - & $X$ \\
\hline $\begin{array}{l}\text { Car } \\
\text { registration } \\
\text { licences }\end{array}$ & $\mathrm{X}$ & $\mathrm{X}$ & - & $\mathrm{X}$ & $\mathrm{X}$ & - & $\mathrm{X}$ & $\mathrm{X}$ & $\mathrm{X}$ & - \\
\hline $\begin{array}{l}\text { Driving } \\
\text { licences }\end{array}$ & $\mathrm{X}$ & $\mathrm{X}$ & - & $\mathrm{X}$ & $\mathrm{X}$ & & $\mathrm{X}$ & $\mathrm{X}$ & $\mathrm{X}$ & $\mathrm{X}$ \\
\hline $\begin{array}{l}\text { Asylum } \\
\text { seeker } \\
\text { documents }\end{array}$ & $\mathrm{X}$ & - & - & - & - & $\mathrm{X}$ & - & - & $\mathrm{X}$ & $\mathrm{X}^{*}$ \\
\hline $\begin{array}{l}\text { Car } \\
\text { insurance } \\
\text { policies }\end{array}$ & $\mathrm{X}$ & $\mathrm{X}$ & - & - & - & - & - & - & $\mathrm{X}$ & - \\
\hline $\begin{array}{l}\text { Stamp } \\
\text { specimens }\end{array}$ & $\mathrm{X}$ & - & $X$ & $\mathrm{X}$ & $\mathrm{X}$ & - & $\mathrm{X}$ & - & $\mathrm{X}$ & - \\
\hline Counterfeits & $\mathrm{X}$ & - & $\mathrm{X}$ & - & $\mathrm{X}$ & - & - & - & $\mathrm{X}$ & - \\
\hline ALERTS & $\mathrm{X}$ & - & - & - & $\mathrm{X}$ & - & - & - & - & - \\
\hline
\end{tabular}

The information systems are a convenient and accessible tool for the officials to check authenticity of documents and detect fraud. The use of information systems speeds up the document verification process in cases of suspicion.

The identification of asylum seekers is greatly affected by the low quality of the documents issued by various countries, sometimes - by errors made by the issuing authorities and by infringements in service. Identity documents are still obtained illegally - fraudulently.

The most important factor influencing the authentication of documents required for border crossing is the illegal production and sale of high-quality counterfeit documents. Technological production methods similar to or even identical to the preparation of authentic documents are used. Document protection elements are also qualitatively simulated. By personalizing stolen and fraudulently obtained blanks of authentic documents, counterfeit documents are made that are difficult to detect. All these factors complicate the identification and authentication process and contribute to the increase in illegal immigration.

\section{Conclusions and suggestions}

1. In order to ensure compliance of the legislation of the Republic of Latvia with the requirements of the European Union in the field of asylum, the new Asylum Law entered into force in 2016 with the aim to ensure human rights to receive asylum, acquire status of refugee or 
alternative status or obtain temporary protection in the Republic of Latvia. The Law determines that the institution responsible for initial activities with asylum seekers and determination of the asylum seeker's identity is the State Border Guard.

2. Information systems are an easy-to-use investigative tool for detecting false documents, available throughout Europe, and their use speeds up the document verification process in cases of suspicion.

3. Examining the information to be included in the specimen document systems, the authors found that specimens of travel documents, residence permits, identification cards, visas can be found in all systems reviewed by the authors; however, documents such as personal insurance policies can only be found in the "DOCIS" information system; specimen of driving licences for transportation of dangerous freights can only be found in the "Reference Manual" and "DPR" systems. The "DOCIS" system is the only one that includes language training tests to improve the knowledge of different national languages. Summarizing all the information, the authors conclude that in all the examined positions the most different types of documents are included in the "Vavere pases" register. Specimens of asylum seekers' documents can be found only in "Vavere pases", "DISCS", "ARKILA".

4. A positive identification result prevents threats to public order and security not only in the particular Member State but also in the European Union as a whole. Therefore, in the process of identifying asylum seekers, the State Border Guard officials have to use a set of several methods, as fingerprint identification system, information system, interrogation methods, examinations, etc., to speed up the asylum procedure and identify the real causes of fleeing.

5. The current Eurodac Regulation allows comparison only of dactyloscopic data. The reform of the Eurodac Regulation proposes the possibility to add biometric identifiers for facial recognition in order to reduce some of the problems faced by the Member States due to noncompliance with the procedure of damaged fingertips and fingerprints.

6. The most common problems in examining asylum seekers' identities are: unwillingness to cooperate, providing false information, use of counterfeit or impostor documents, impersonation of minors, concealment or repeated change of identity.

7. Investigating the reasons for concealing the person's identity, it was found that the asylum seeker feels unstable and insecure in the country where he has applied for international protection, does not trust the State Border Guard officials, fears that if he/she discloses his/her real data, he/she may be found by the persons who had threatened or persecuted him/her. 
8. The factors interfering determination of the authenticity of a document are: low quality of documents issued by various countries, errors in the procedure of personalization or issuing the documents, infringement of issuing procedures, illegal acquisition of documents.

9. Specimen document information systems do not include information on the various elements of document protection, sometimes the information provided is inaccurate or erroneous, nonetheless the system operators do not yet have any responsibility or liability for the information uploaded in the system.

\section{The authors' proposals:}

In order the officials of the State Border Guard Examination Service could officially order specimens of documents or forms necessary for their operations from the co-operation structural units and from abroad, the authors recommend to amend Article15 "Forensic expert has rights" of the Forensic Expert Law adding Section 4 that would state "To order and receive all specimens of documents and forms necessary for the examination".

The authors believe that the Latvian State Border Guard officials should share with other European Union member states their experience in establishing an asylum seekers register, because this national information system in Latvia works successfully, including many functions that have not yet been implemented in the other member states.

Face recognition is not the only proposal that can complement and improve the existing system, therefore the authors recommend amending Regulation No 603/2013 of the European Parliament and of the Council "On the establishment of Eurodac for the comparison of fingerprints for the effective application of Regulation (EU) No 604/2013 establishing the criteria and mechanisms for determining the Member State responsible for examining an application for international protection lodged in one of the Member States by a third-country national or a stateless person and on requests for the comparison with Eurodac data by Member States' law enforcement authorities and Europol for law enforcement purposes, and amending Regulation (EU) No 1077/2011 establishing a European Agency for the operational management of large-scale IT systems in the area of freedom, security and justice":

- in order to be able to identify a person more accurately and not cause inconvenience with the touches of direct contact, to introduce a contactless biometric identification method-an iris recognition program; Article 2 "Definitions" and Article 15 "Data entry" of the Regulation (EC) No 603/2013 of the European Parliament and of the Council should be supplemented with text "biometric data- digital 
image of the iris"; Article 1 "The following terms are used in the Law" of the Biometric Data Processing System Law should also be supplemented with the term "digital image of the iris";

- in order to determine the country of origin and even the region from which the asylum seeker comes, to introduce a voice recognition program according the dialect; Article 2 "Definitions" and Article 15 "Data entry" of the Regulation of the European Parliament and of the Council No 603/2013 shall be supplemented with "biometric data voice recording"; Article 1 "The following terms are used in the Law" of the Biometric Data Processing System Law " should be supplemented with the term "voice recording".

To rule out impostor during the inspection, the State Border Guard officials must carefully compare the photograph in the document with the person's face, which must be divided into segments. The authors recommend that annual training on recognizing impostors should be organized for the officials who identify persons on the basis of presented documents, as the number of the impostor cases in which the another person's documents are used is increasing every year.

In order to exclude the possibility of illegal copying or alteration of documents, the identity documents issued must incorporate all the security features included in the description of the specimen document. The Office of Citizenship and Migration Affairs, which is an identity document issuing authority in Latvia, should appoint a responsible person for quality control of the obtained forms, because in 2019 it was found that a whole batch of authentic documents - identification cards of the Republic of Latvia - did not incorporate such a security element as a variable laser image.

The authors recommend making amendments to the sentence of Article 11 of the "Regulations on the development and use of the information system of specimen documents of personal identity and documents certifying rights" by adding the words "at the request of the State Border Guard officials".

In order to combat document fraud and to support the fast exchange of authentic or false document images between the EU Member States or third countries, the European Union Internet Image Archiving System (iFADO) should introduce stricter rules for maintaining specimen document information systems by appointing 2-3 responsible persons from the each country's national Expertise institutions that will place the description of the document in the common system, setting a term of 1 month before the document is introduced into circulation. 


\section{References}

1. ADIJĀNE, I. (2019). Asylum procedure in Latvia - a part of common European asylum system. Proceedings of the International Scientific and Practical conference "Border Security And Management". DOI: http://dx.doi.org/10.17770/bsm.v2i7.3494

2. BURBERGS, M., \& KUČS, A. (2019). Vispārējai cilvēktiesību deklarācijai - 60. Jurista $v \bar{a} r d s, 48$ (553).

3. BUSCH, C., CAILlEBOTTE, SEIDEL, S., KNOPJES, F., MALTONI, D., FERRARA, M., VELDHUIS R., SPREEUWERS, L., RAJA, R., RAGHAVENDRA, K., GOMEZ-BARRERO, M., \& RATHGEB, C. (2019). The Challenge of Morphing for Border Control. MAD Action Plan. Frontex. Retrieved October 5, 2020, from https://christoph-busch.de/files/Busch-Frontex-MAD-191009.pdf

4. Eiropas Ekonomikas un sociālo lietu komitejas atzinums par tematu "Komisijas paziñojums Eiropas Parlamentam, Padomei, Eiropas Ekonomikas un sociālo lietu komitejai un Reǵionu komitejai “Eiropas programma migrācijas jomā"”" (2015). Eiropas Savienības Oficiālais Vēstnesis. Retrieved October 5, 2020, from https://eur-lex.europa.eu/legal-content/LV/TXT/PDF/?uri=CELEX:52015AE4319\&f rom $=\mathrm{DE}$

5. GAVEIKA, A., \& BULGAKOVA, I. (2018). Asylum law regulation and current events of its application in Latvia. Proceedings of the International Scientific and Practical conference "Border Security And Management". Retrieved October 5, 2020, from http://journals.ru.lv/index.php/BSM/article/view/1700/1520.

https://howlingpixel.com/i-lv/Vispārējā_cilvēktiesību_deklarācija.

6. YAHAYA, Y., ISA, M., \& AZIZ, M. (2009). Fingerprint Biometrics Authentication on Smart Card, Proceedings of 2009 Second International Conference on Computer and Electrical Engineering, 671-673. DOI: 10.1109/ICCEE.2009.155 Retrieved October 5, 2020, from https://ieeexplore.ieee.org/abstract/document/5380542/authors\#authors

7. MEIKALIŠA, Ā., \& STRADA, K. (2002). Kriminālprocesuālo terminu skaidrojoša vārdnīca, Rīga: RaKa.

8. MURRIE, D., BOCCACCINI, M., GUARNERA, L., \& RUFINO, K. (2013). Are forensic eksperts biased by the side that retained them? Psychological Science, 24 (10), 1889-1897. https://doi.org/10.1177/0956797613481812.

9. SHILPA, M., SHANKHA, B., ANEETA, R., \& KRISHNA, S. (2018). Support for Resettling Refugees: The Role of Fixed Versus Growth Mind-Sets. Psychological Science, 2 (30), 238-249. https://doi.org/10.1177/0956797618813561.

10. SILINIECE, I., \& GAIGALNIECE-ZELENOVA, J. (2018). Introduction of biometric data processing system in the state border guard. Proceedings of the International Scientific and Practical conference "Border Security And Management". DOI: http://dx.doi.org/10.17770/bsm.v2i7.3481. 